\title{
$\mathrm{Al}-\mathrm{Mg}-\mathrm{Si}$ 系合金の曲げ変形初期の亀裂発生および 伝播に及ぼすミクロボイドの影響
}

\author{
山本 裕介**浅野 峰生*.吉田 英雄* \\ 小林 正和 $* *$. 戸田 裕之***
}

Journal of The Japan Institute of Light Metals, Vol. 63, No. 12 (2013), 452-457

(C) 2013 The Japan Institute of Light Metals

\section{Effect of micro-voids on crack initiation and propagation in bending deformation of $\mathrm{Al}-\mathrm{Mg}-\mathrm{Si}$ alloy sheets}

\author{
Yusuke YAMAMOTO*, Mineo ASANO*, Hideo YOSHIDA* \\ Masakazu KOBAYASHI ${ }^{* *}$ and Hiroyuki TODA***
}

\begin{abstract}
The crack initiation and the propagation during bending have been considered to be affected by second phase particles with micro-voids and shear-band. However, the effect of second phase particle distribution on formation of micro-voids, and the effect of micro-voids on crack initiation and propagation during bending have not been fully investigation. In this study, the effect of second phase particle distribution on formation of micro-voids, and the effect of micro-voids on crack initiation and propagation during bending were investigated by using the largest synchrotron radiation facility "SPring-8" and FE-SEM/EBSD. With increasing the bending ratio, micro-voids were increased around coarse particles nearby outer surface. In particular, coarse micro-voids were formed around coarse particles with high aspect ratio on shear-bands. At large cracking part, the coarse micro-void was observed at outmost layer section as crack initiation site, and coarse micro-voids and sheared fracture surface were observed at crack propagation site. At small cracking part with no propagation, Cube orientation grains were located under the small crack. It was considered that these cube orientation grains inhibited the formation of shear-bands, therefore propagation of cracks did not occur at small cracking area.
\end{abstract}

(Received July 11, 2013 Accepted September 1, 2013)

Keywords: Al-Mg-Si alloy, bending, micro-void, second phase particle, crack propagation, crack initiation, cube orientation

\section{1. 緒言}

近年, $\mathrm{CO}_{2}$ 排出量削減の観点から自動車の軽量化を目的と して, 自動車ボデイパネル等へのアルミニウム合金板の適用 が拡大している。自動車ボディパネル用アルミニウム合金板 材として，主に $\mathrm{Al}-\mathrm{Mg}$ 系合金拀よびAl-Mg-Si系合金が使用 されており，プレス成形時にストレッチャストレインマー クが発生しないこと，塗装焼付硬化性を有することなどか ら，Al-Mg-Si系合金のT4調質材が主流となっている。フー ドやドア等のアウタパネルは, 縁でインナパネルをかしめる 曲げ加工（ヘミング）を行うが, $\mathrm{Al}-\mathrm{Mg}-\mathrm{Si}$ 系合金の T4 調質 材は室温時効の進行に伴って曲げ加工性が低下し, 曲げ加工 時に割れが発生しやすくなる ${ }^{1)}$ 。そのため, 曲げ加工性の改 善が強く望まれており，曲げ割れ発生メカニズムの解明に向

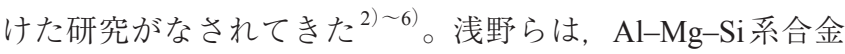
板に执いて, 曲げ加工によるせん断帯の形成と全第2 相粒子
数 $(2 \mu \mathrm{m}$ 以上) が共に多い場合，曲げ加工性が低下するこ とを報告しており，以下の曲げ割れメカニズムを提案してい $ろ^{2)}$ 。

(1) 曲げ加工度の増加に伴って, 第 2 相粒子周りでのミク ロボイドの形成が進行

(2) 曲げ加工度の増加に伴って, せん断帯の形成が進行

(3) せん断帯とミクロボイドに沿って割れが伝播

曲げ加工中に形成されたミクロボイドの形成状態の観察 は, 一般的に樹脂埋め, 研磨された試料を用いた光学顕微鏡 観察もしくは走査型電子顕微鏡観察により行う。しかし, 前 述の方法では数 $\mu \mathrm{m}$ 以下のミクロボイドの形成状態を正確に 捉えることが非常に難しいため, ミクロボイドの形成状態 に及ぼす第 2 相粒子分布の影響や曲げ割机初期の亀裂発生に 及ぼすミクロボイドの影響は十分には明らかにされておら ず，推測の域を脱していない。近年，大型放射光施設を利用 した3D/4D 観察技術の発展に伴い, $1 \mu \mathrm{m}$ 程度のミクロボイ

*株式会社UACJ 技術開発研究所（ ₹ 455-8670 愛知県名古屋市港区千年3-1-12）。 Research and Development Division, UACJ Corporation (3-1-12 Chitose, Minato-ku, Nagoya-shi, Aichi 455-8670). E-mail: yamamoto-yusuke@uacj.co.jp

**豊橋技術科学大学機械工学系 (豊橋市)。Department of Mechanical Engineering, Toyohashi University of Technology (Toyohashi-shi, Aichi).

***九州大学工学研究院機械工学部門 (福岡市)。Department of Mechanical Engineering, Kyushu University (Fukuoka-shi, Fukuoka). 
Table 1 Chemical composition of specimens (mass\%).

\begin{tabular}{c|c|c|c|c|c|c|c|c}
\hline \hline $\mathrm{Si}$ & $\mathrm{Fe}$ & $\mathrm{Cu}$ & $\mathrm{Mn}$ & $\mathrm{Mg}$ & $\mathrm{Cr}$ & $\mathrm{Zn}$ & $\mathrm{Ti}$ & $\mathrm{Al}$ \\
\hline 1.0 & 0.17 & 0.02 & 0.07 & 0.52 & $\mathrm{Tr}$. & 0.19 & 0.02 & Bal. \\
\hline
\end{tabular}

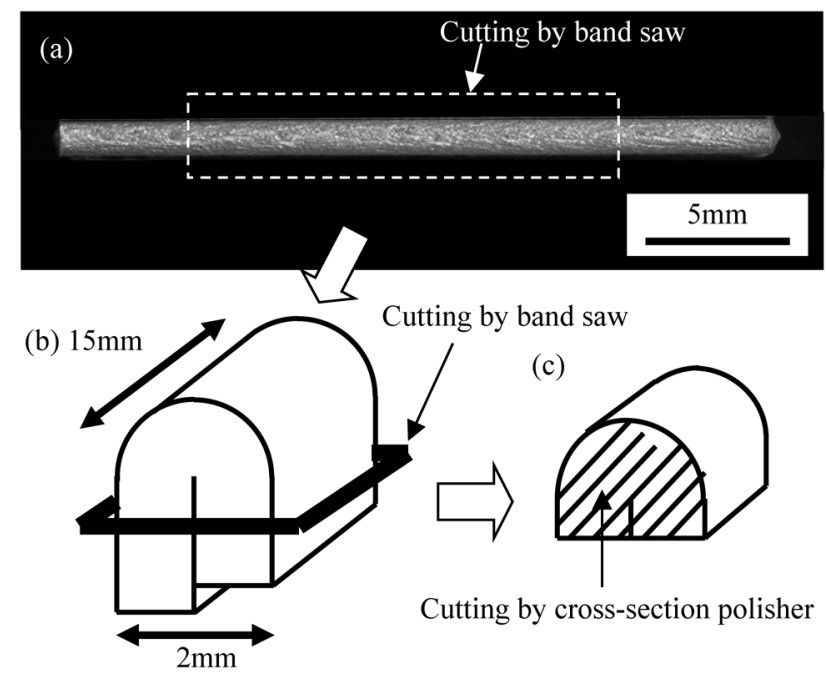

Fig. 1 Appearance and schematic diagram of bending test sample. (a) Appearance of sample surface. (b) and (c) Schematic diagram for sample preparation. (b) For tomography measurement. (c) For SEM observation.

ドの観察が実現可能となってきた ${ }^{7), 8)}$ 。そこで, 本研究では, SPring-8 を利用したX線 CT 観察を行った後, 同一試料にて SEM 観察を行い，ミクロボイドの形成状態に及ぼす第 2 相粒 子の影響を調査した。その結果を基に，曲げ割れ初期の亀裂 発生に及ぼすミクロボイドの影響について考察した。

\section{2. 実験方法}

Table 1に示す化学成分を有する $\mathrm{Al}-\mathrm{Mg}-\mathrm{Si}$ 系合金鋳塊を均 質化処理，熱間圧延，冷間圧延，溶体化処理により $0.9 \mathrm{~mm}$ の T4板材とした。曲げ試験は, 圧延方向に対して $0^{\circ}$ 方向の 押曲げ法（JIS Z2248）により, 内側曲げ半径 $0 \mathrm{~mm} の 180^{\circ}$ 曲 げ試験（密着曲げ試験）を行った。曲げ試験片の外観および 模式図を Fig. 1に示す。Fig. 1（b）に示すように曲げ試験片の 先端から 1 辺約 $2 \mathrm{~mm}$ の棒状試料を切出し, 大型放射光施設 SPring-8のBL20XUにおいて，ミクロボイドおよびAl-Fe-Si 系粒子の観察を行った。Fig. 2に示すようにサンプルをセッ ティングし, 透過X線を可視光に変換した後, レンズで拡大 してから可視光の強度を検出した。これにより，1 $1 \mu \mathrm{m}$ 程度 の微小なミクロボイドや $\mathrm{Al}-\mathrm{Fe}-\mathrm{Si}$ 系粒子を観察することが できる。CT断層像から特徴的な断面を選択し, 該当断面が 得られるよう, Fig. 1(c) に示すようにクロスセクションポ

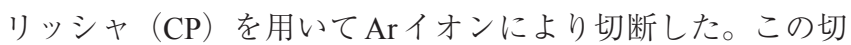
断面において，SEM観察およびEBSD解析を行った。

\section{3. 試験結果および考察}

\section{1 ミクロボイドの形成}

Fig. 3 に曲げ試験片先端部の 3 次元再構成像およびCT 断層 像を示す。板厚内部まで伝播した割れ (Fracture), 局所的な くびれ (Localized necking) や微小な割れ (Crack), 曲げ加

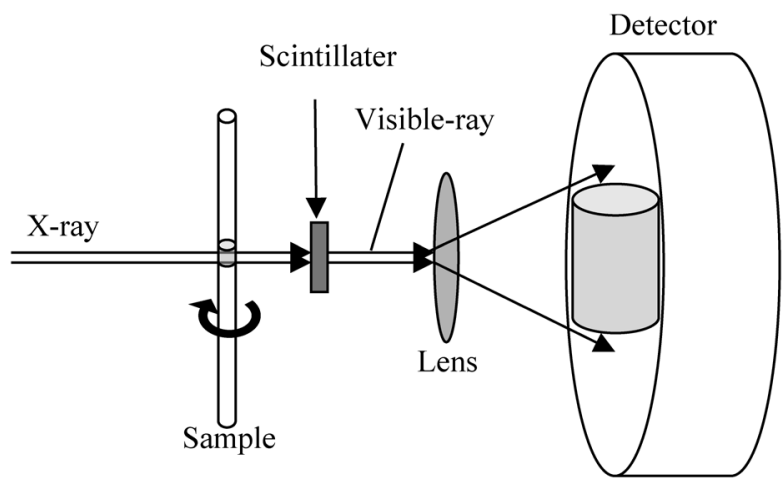

Fig. 2 Schematic diagram of sample setting for tomography measurement.

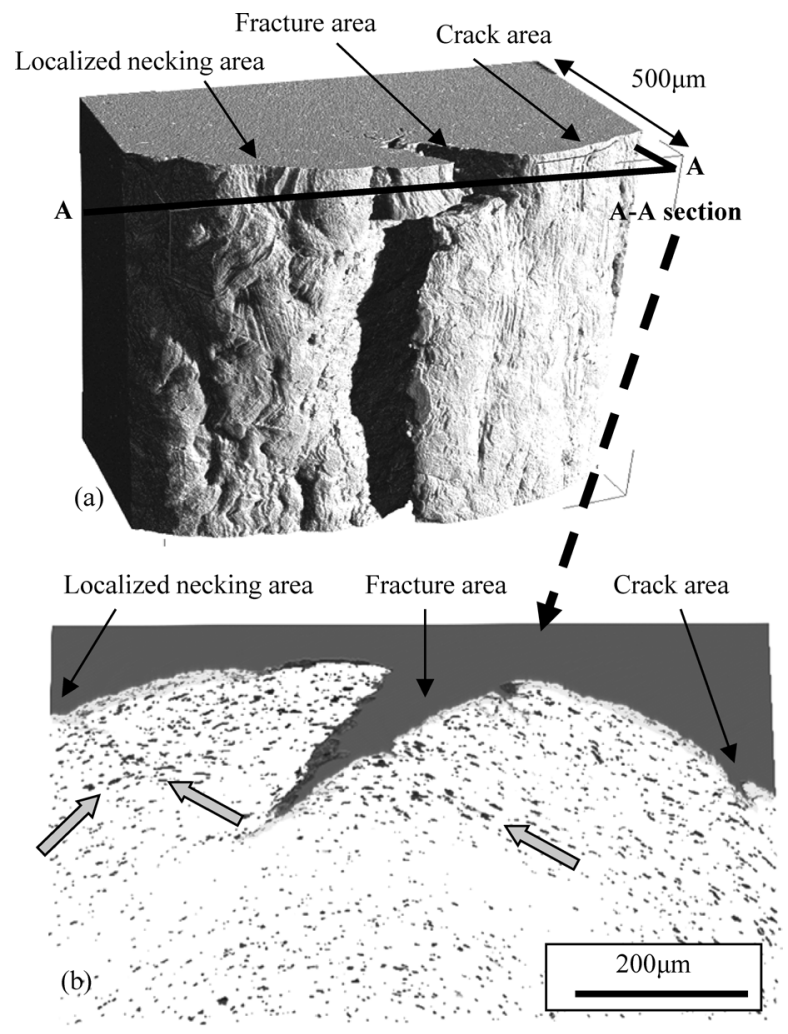

Fig. 3 3D perspective views and 3D rendered tomographic volumes of bending test sample. (a) Perspective views. (b) Rendered tomographic volumes. Black points are micro-voids.

工部外面に現れた変形帯が観察された。A-A断面における $\mathrm{CT}$ 断層像は，厚さ $5 \mu \mathrm{m}$ を重ね合せた像であり，黒点がミク ロボイドである。ミクロボイドは，表層近傍で顕著に形成さ れており, Fig. 3(b) 中に矢印で示すように特に局所くびれ 領域の延長上で粗大なミクロボイドが形成されていた。詳細 は後述するが, 局所くびれ領域の延長上ではせん断帯が形成 されており，せん断帯上でミクロボイドの形成が顕著であっ た。

また，ミクロボイドの板厚方向の分布に着目すると，ミク ロボイドは表層近傍で多く, 板厚 $1 / 4$ 部で減少した後, 板厚 中心部で再度増加した。Fig. 4に曲げ部の全板厚における反 射電子像を示す。EDS 分析の結果, 黒点がミクロボイド, 白 点が $\mathrm{Al}-\mathrm{Fe}-\mathrm{Si}$ 系粒子であった。Fig. 3に示した CT 断層像と 


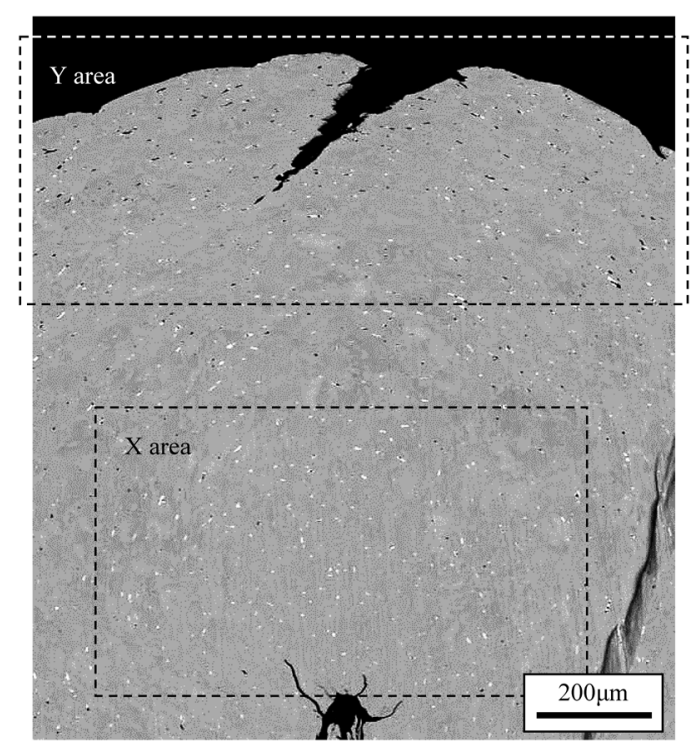

Fig. 4 SEM image through gauge of bending test sample. Black points are micro-voids. White points are particles.
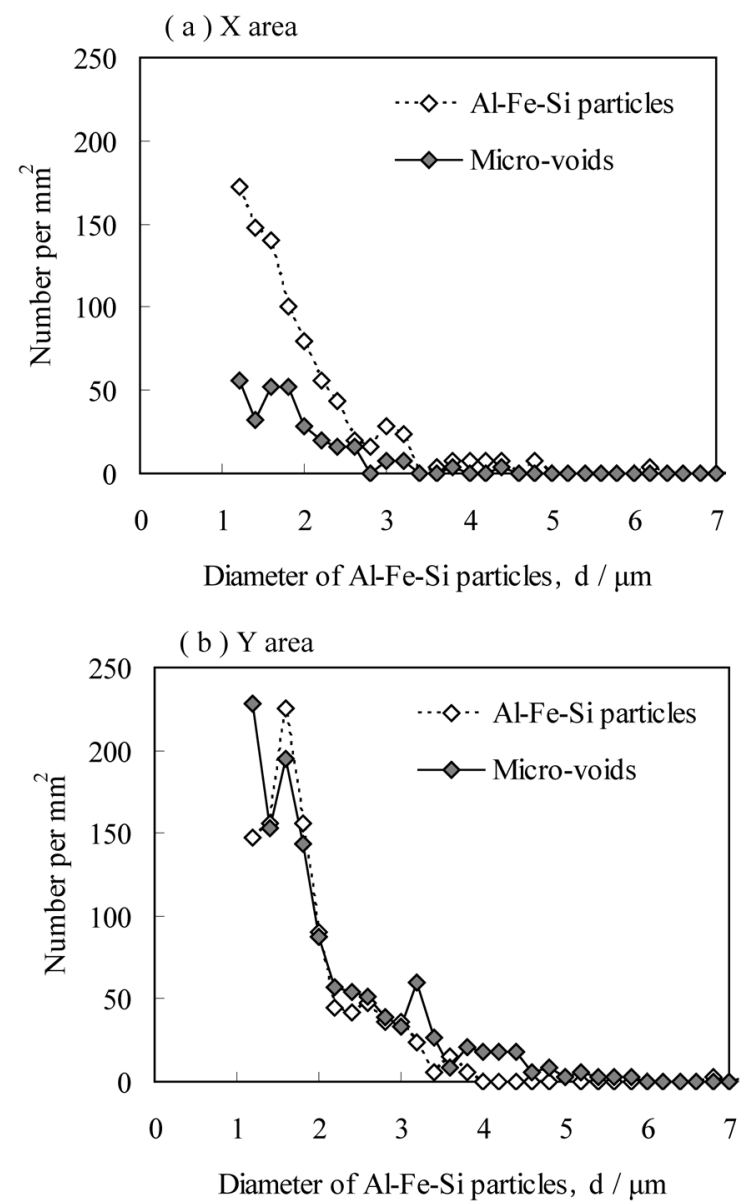

Fig. 5 Relation with histogram of Al-Fe-Si particles and histogram of micro-voids. (a) $\mathrm{X}$ area in Fig. 4. (b) $\mathrm{Y}$ area in Fig. 4.

同様に，ミクロボイドは表層近傍で多く，板厚 $1 / 4$ 部で減少 した後, 板厚中心部で再度増加した。さらに板厚 $3 / 4$ 部から 内側表層部 (内側曲げ部) にかけて, ミクロボイドはほとん ど観察されなかった。このようなミクロボイドの分布状態か ら, 板厚中心部で形成されたミクロボイドは, 曲げ加工の歪

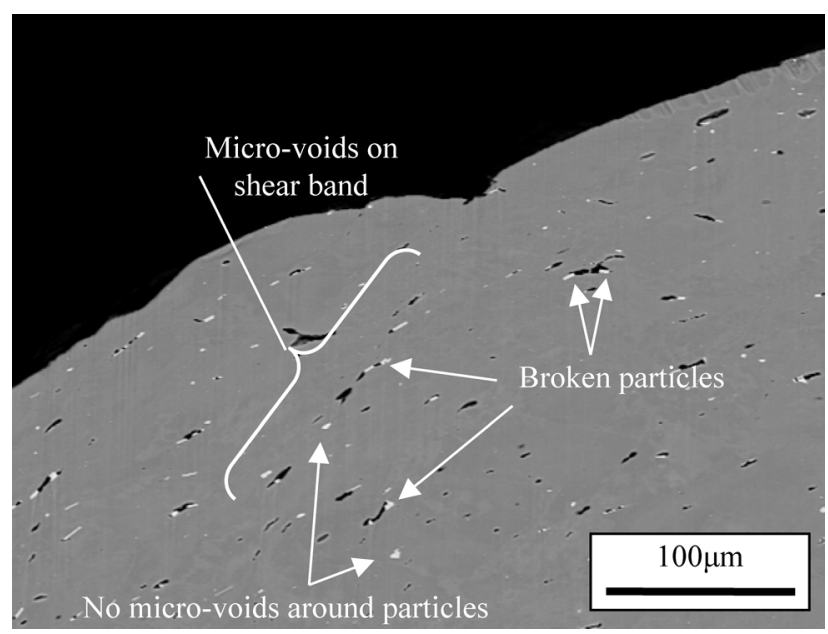

Fig. 6 SEM image of localized necking area.

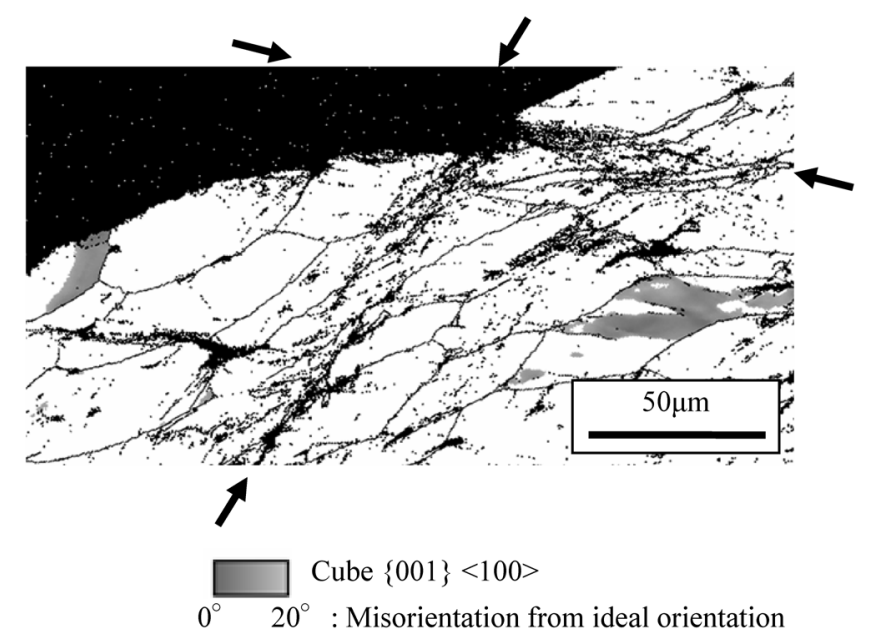

Fig. 7 Crystal orientation map at localized necking area. Black lines are large angle grain boundaries $>15^{\circ}$. Black area is the area of CI value $<0.1$.

分布が主原因ではなく，鋳造時に形成されたミクロボイドが 圧延後も残存していたものと考えられる。しかし，板厚中心 部のミクロボイドは曲げ割れの発生には直接影響しないた め, 形成原因の詳細については今後の研究課題とした。

Fig. 4中のX 領域，Y 領域に扔いて $\mathrm{Al}-\mathrm{Fe}-\mathrm{Si}$ 系粒子とミク ロボイドの粒度分布を画像解析により計測した。その結果を Fig. 5に示す。Al-Fe-Si系粒子について, X 領域よりも Y 領 域の方が $2 \mu \mathrm{m}$ 以下の粒子数が多かった。一方, ミクロボイ ドについて，X領域よりも Y 領域の方が $3 \mu \mathrm{m}$ 以下のボイド 数が多く, $\mathrm{Al}-\mathrm{Fe}-\mathrm{Si}$ 系粒子とミクロボイドの粒度分布が近い 值を示した。このことから, 曲げ加工部の外側領域（引張変 形領域）に拈けるミクロボイドの形成は， $\mathrm{Al}-\mathrm{Fe}-\mathrm{Si}$ 系粒子の 粒度分布が影響を及ぼしていると推測される。

Fig. 6にFig. 3中の局所くびれ領域の反射電子像を示す。 ミクロボイドの両端もしくは片側の端部に $\mathrm{Al}-\mathrm{Fe}-\mathrm{Si}$ 系粒子 が存在している様子が多く観察された。以上のことから, 曲 げ加工度の増加に伴い, (1) $\mathrm{Al}-\mathrm{Fe}-\mathrm{Si}$ 系粒子が割れ, その隙 間にミクロボイドが形成された，もしくは(2) $\mathrm{Al}-\mathrm{Fe}-\mathrm{Si}$ 系粒 子と母相の界面が剥離し, 剥離面でミクロボイドが形成され たと考えられる。ここで, 複数の CT 断層像を用いて $\mathrm{Al}-\mathrm{Fe}-$ 
(a) $X$ area

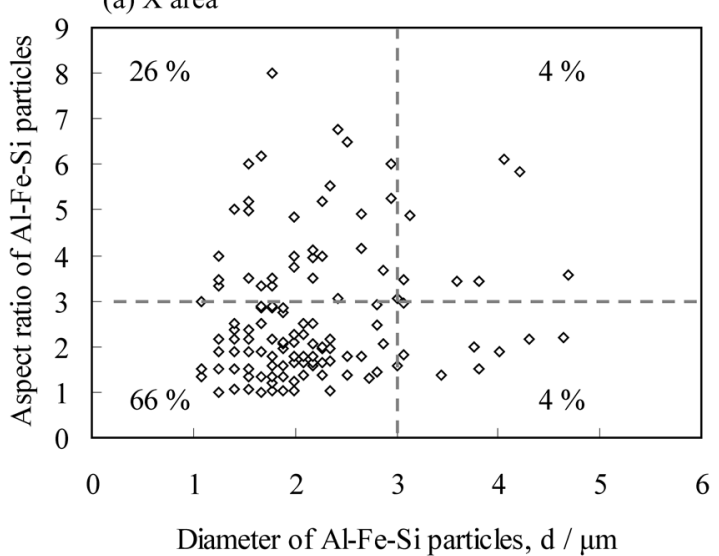

(b) $\mathrm{Y}$ area

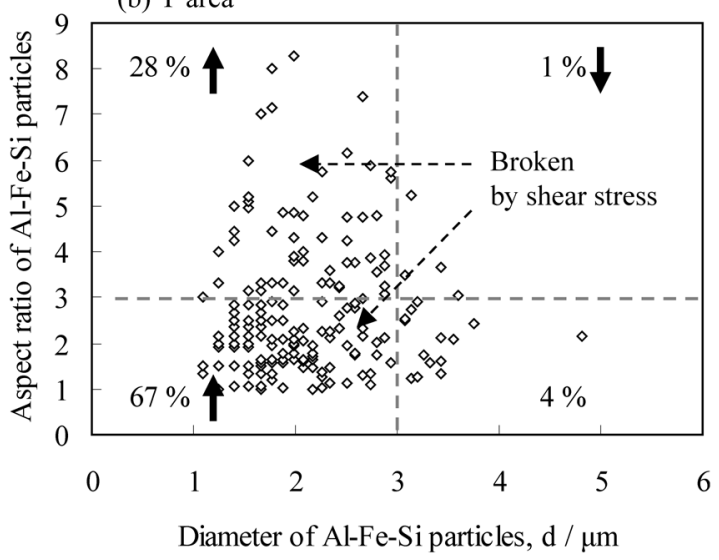

Fig. 8 Scatter diagram of Al-Fe-Si particles. (a) $\mathrm{X}$ area in Fig. 4. (b) Y area in Fig. 4.

$\mathrm{Si}$ 系粒子とミクロボイドの形成状態を確認したが，両端に $\mathrm{Al}-\mathrm{Fe}-\mathrm{Si}$ 系粒子が存在するミクロボイドが多く見られたこ と, ミクロボイドの形成を伴わない粗大な $\mathrm{Al}-\mathrm{Fe}-\mathrm{Si}$ 系粒子 も存在することから，(1)の機構が優位であると考えられる。 このほか, (3)元々材料中に存在したミクロボイドが曲げ加工 度の増加に伴って大きくなる，(4) $\mathrm{Mg}_{2} \mathrm{Si}$ またはシリコン粒子 に関連してミクロボイドが形成されるケースも考えられる。 これらの点を確認するためには，アルミニウムとX線吸収係 数の差が小さい $\mathrm{Mg}_{2} \mathrm{Si}$ およびシリコンに関して回折を利用し たトモグラフィ ${ }^{9)}$ を行うなど，より精度の高い測定を行う ことが必要であり，今後の課題としたい。

Fig. 7に局所くびれ領域のEBSD解析結果を示す。方位差 $15^{\circ}$ 以上の大角領域を黒線で示し, CI 值（同定された方位の 信頼值，最大值は1）０.1 以下の領域は黒点で表示した。理想 方位から $20^{\circ}$ 以内のCube方位粒はグレーで表示した。CI值が 0.1 以下となるケースは, 歪が局在化している, 測定点に疵 や異物，第 2 相粒子が存在していると考えられるが，矢印部 のように帯状かつ断続的に存在している場合, 歪が局在化し ている部分，すなわち，せん断帯が形成されている部分と考 えられる。Fig. 3, Fig. 6に見られるようにせん断帯上でミク ロボイドが顕著に形成されていることから，せん断帯上では $\mathrm{Al}-\mathrm{Fe}-\mathrm{Si}$ 系粒子の内部応力が上昇しやすく, 粒子の割れに伴 うミクロボイドの形成が顕著であったと考えられる。このよ うに粒子の割れに伴ってミクロボイドが形成されるのであれ ば，粒子のサイズだけでなく形状によっても，ミクロボイド

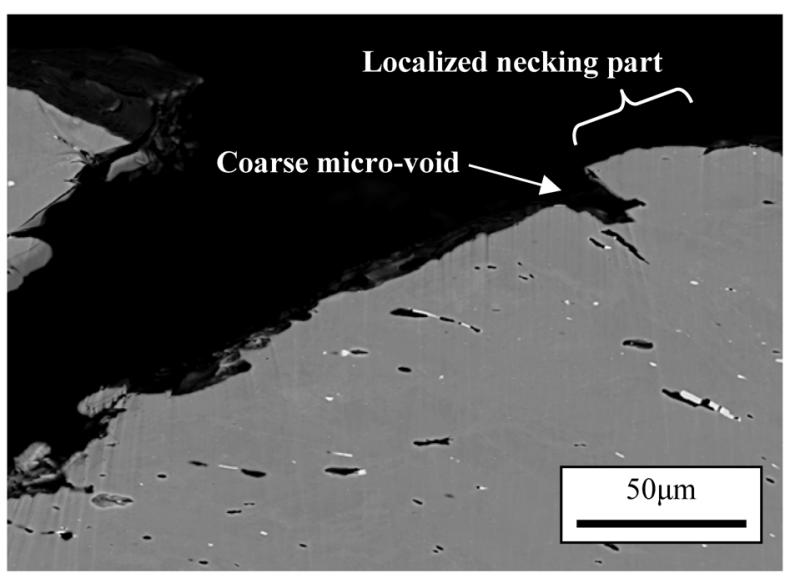

Fig. 9 SEM image of fracture area.

の形成されやすさが変化すると考えられる。

Fig. 8 に Al-Fe-Si 系粒子のサイズとアスペクト比と粒 径 (円相当直径) の関係を示す。Fig. 4中 X 領域の Al-Fe-Si 系粒子は曲げ加工度の増加に伴う割れがほとんど起こってい ない。この部分では, 円相当直径が $3 \mu \mathrm{m}$ 以下かつアスペク 卜比 3 以下の粒子が $66 \%$ 存在するが, 円相当直径が $3 \mu \mathrm{m}$ 以 上かつアスペクト比 3 以上の粒子も $4 \%$ 存在する。一方, 外 側表層部（Fig. 4中 Y 領域）では, 円相当直径が $3 \mu \mathrm{m}$ 以上か つアスペクト比 3 以上の粒子の割合のみが大幅に減少してい る。このことから, 曲げ加工に伴う粒子の割れは粒子サイズ が大きいだけではなく，アスペクト比が高いほど起こりやす いと考えられる。

\section{2 曲げ割れ初期の亀裂発生およびその伝播}

局所的なくびれ (Localized necking), 板厚内部まで伝播し た割れ（Fracture），微小な割れ（Crack）が発生した各部位 におけるSEM観察結果を基に割れの発生および伝播におけ るミクロボイドの役割については以下のように考えられる。

Fig. 6に示した局所くびれ領域のSEM観察結果において, 局所くびれ領域の最表層で微小なミクロボイドが形成され開 ロしているが，割れは内部まで伝播しなかった。

Fig. 9に板厚内部まで割れが伝播した領域のSEM観察結果 を示す。最表層において, 局所くびれが発生した痕跡およ び粗大なミクロボイドが形成されていた痕跡が観察された。 Fig. 10に板厚内部まで割れが伝播した領域の破面観察結果 を示す。ミクロボイドの痕跡と思われる粒子状の空洞部とそ の下にせん断破面が観察された。せん断帯上に形成されたミ クロボイドとせん断带に沿って割れが伝播したと考えられ る。Fig. 10の一部でディンプル状の破面（延性破面）が観察 されるが, せん断帯の形成されていない結晶粒が周囲の亀裂 伝播応力より引きちぎられて形成されたと考えられる。以上 のことから，板厚内部まで割れが伝播した領域では，局所く びれが発生した箇所の最表層で粗大なミクロボイドが形成さ れ，これが開口することで割れの発生起点になり, さらにせ ん断帯上に形成されたミクロボイドとせん断帯に沿って割れ が伝播したと考えられる。

Fig. 11に微小割れ領域のSEM観察結果を示す。微小割れ 領域では, 最表層で粗大なミクロボイドが開口し, 微小割れ が形成されていた。この部分では, 局所くびれがほとんど発 生しておらず，せん断帯の形成およびせん断帯上でのミクロ 


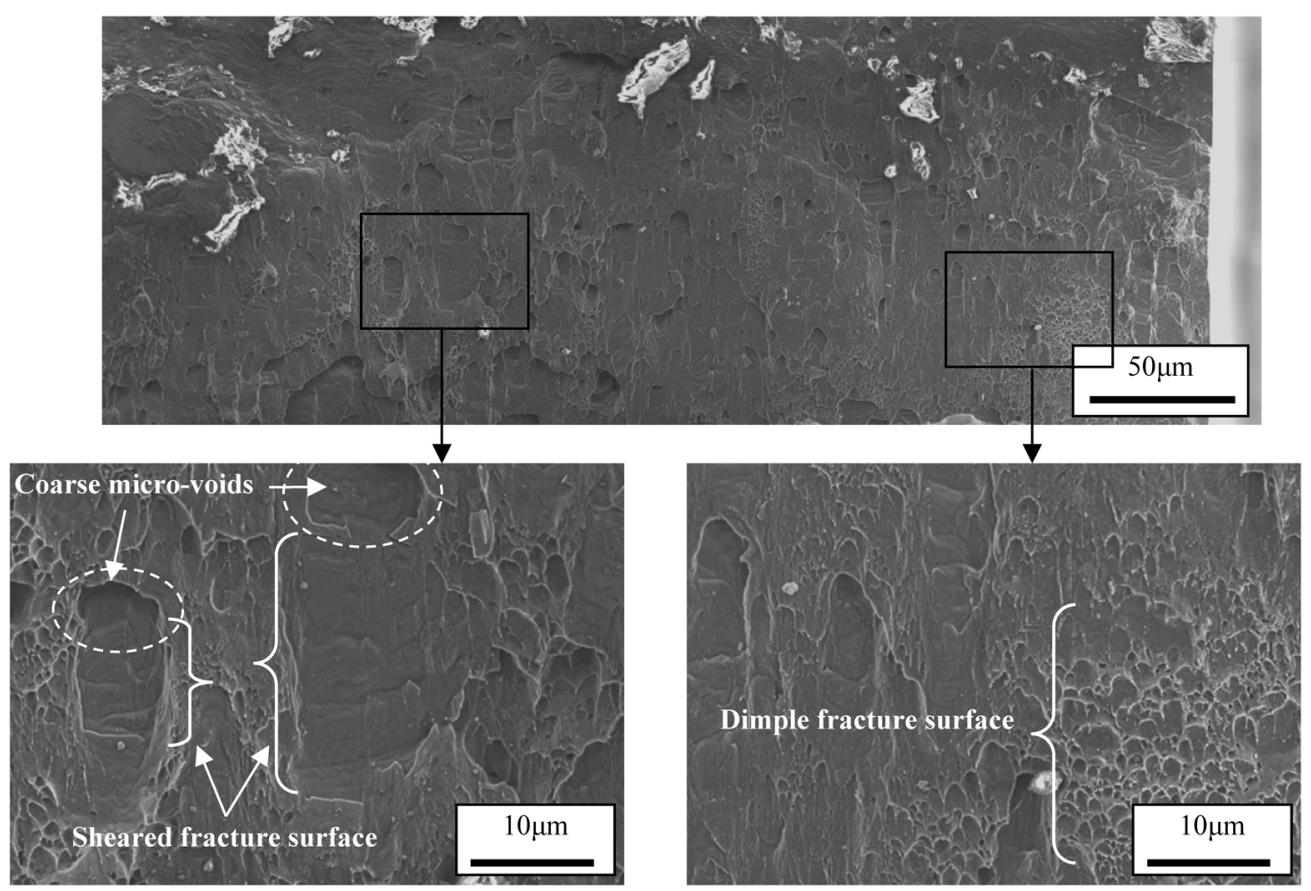

Fig. 10 Fracture surface morphology at fracture area.

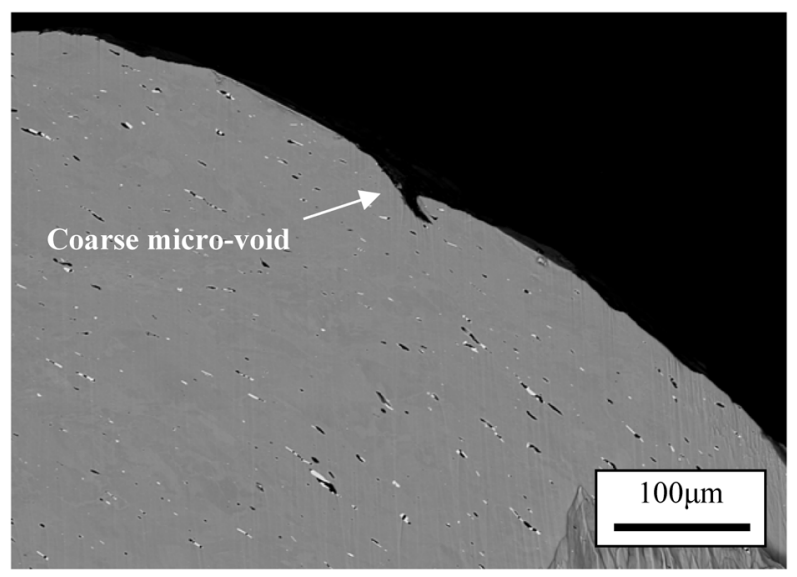

Fig. 11 SEM image of crack area.

ボイドの形成も顕著ではなかった。そのため, ミクロボイド とせん断帯に沿った割れが伝播しにくく，板厚内部へ割れが 伝播しなかったと考えられる。この領域において，せん断帯 の形成が顕著でなかった理由については以下のように考えら れる。

浅野 ${ }^{5)}$ らおよび竹田ら ${ }^{6)}$ は曲げ加工性に及ぼす結晶方位 の影響は大きく，特にCube方位は曲げ加工時にせん断帯が 形成されにくく，曲げ割れが発生しにくい結晶方位である ことを報告している。Fig. 11と同一視野にて EBSD解析を 行った結果，Fig. 12に示すように，微小割れ領域の直下では Cube方位粒が存在していた。以上のことから，この領域で は，せん断帯の形成が軽微であり，割れが伝播しにくかった と考えられる。

\section{3 曲げ割れ発生メカニズム}

メカニズムの模式図を Fig. 13に示す。3.1, 3.2 項で示した 結果より，曲げ割れ発生メカニズムは以下のように考えられ

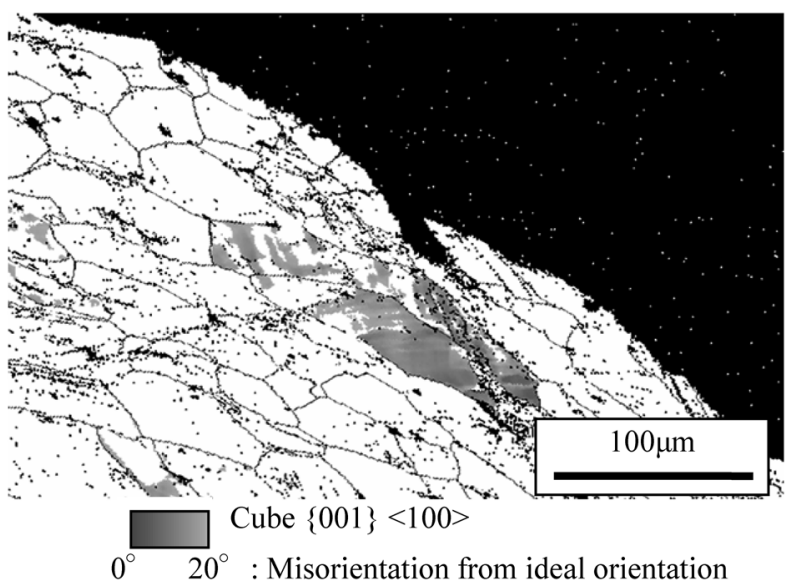

Fig. 12 Crystal orientation map at crack area. Black lines are large angle grain boundaries $>15^{\circ}$. Black area is the area of $\mathrm{CI}$ value $<0.1$.

る。

曲げ加工度の増加に伴い,

(1) 変形量の大きい表層近傍でせん断帯が形成（最表面には 局所的なくびれが生じる, Fig. 13(a))。

(2) 表層近傍で粗大な第2相粒子が割れ，ミクロボイドが形 成（せん断帯上でより顕著に形成，Fig. 13(a))。

さらに曲げ加工度が増加すると，

(3) 最表層のミクロボイドが開口し, 割れの起点 (Crack) になる(Fig. 13(b))。

(4) ミクロボイドの開口部に歪が局在化し, せん断帯上に形 成されたミクロボイドとせん断帯に沿って割れ（Crack） が伝播（Fig. 13(b))。

ただし，割れの起点が形成された近傍にCube 方位粒が存 在した場合, せん断帯が形成されにくいため割れが伝播しに くい。

Fig. 13に示した模式図は平面図（2D）として簡略化した 

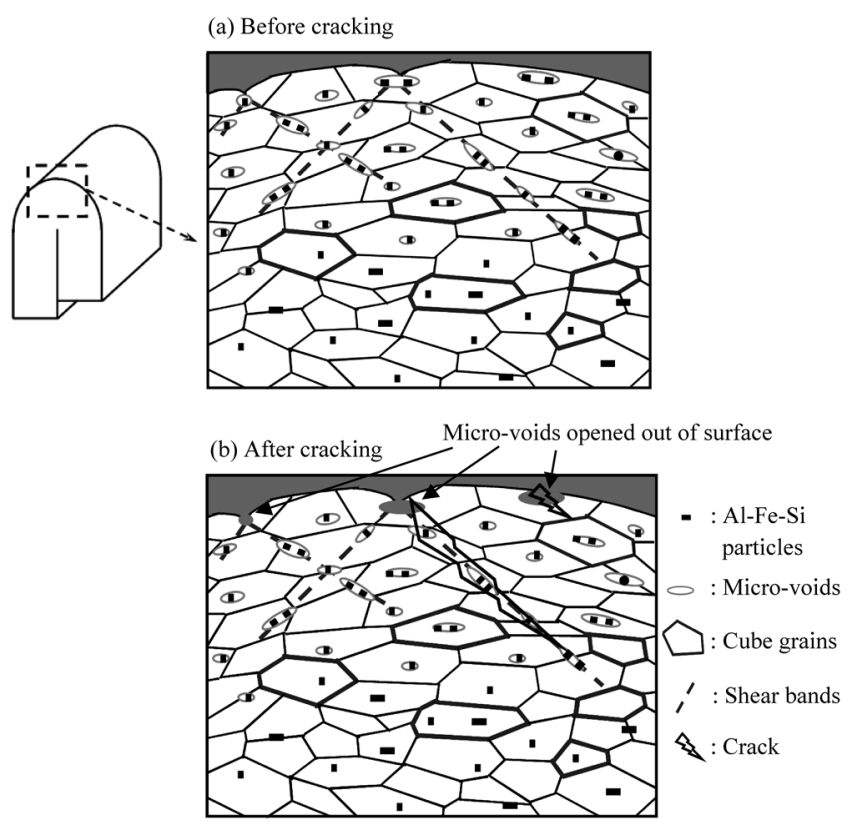

Fig. 13 Schematic diagram for cause of the crack by bending process. (a) Before cracking. (b) After cracking.

ものであり，実際の現象（3D）とは厳密には異なると思わ れる。特に，割れの発生と伝播に対しては，断面図の奥行き 方向の平均情報が重要である。例えば割れの起点と伝播につ いて，最表層の開口したミクロボイドの分布状態と各方位の 結晶粒の分布状態により, 歪の局在化の程度が変化し, どの 位置から割れが伝播するかどうかが決まると考えられる。

本研究ではFig. 3に示したCT測定部全体の断層像を確認 し，抄おむ上記のメカニズムに沿うことを確認している が，客観的にメカニズムの裏づけをとるためには，曲げ加工 の前, 中, 後において, 同一視野の CT 測定を行い, ミクロ ボイドと $\mathrm{Al}-\mathrm{Fe}-\mathrm{Si}$ 系粒子の分布状態の変化を観察する必要 があり，今後の課題としたい。

\section{4. 結言}

樹脂埋め・研磨された曲げ試験片断面の観察では正確に把
握できなかった曲げ割れに及ぼすミクロボイドの影響につい て、 SPring-8を用いたX線 CT 観察と試料調整方法を改善し たSEM観察により，以下のことが明らかになった。

(1) ミクロボイドの形成

表層近傍の $\mathrm{Al}-\mathrm{Fe}-\mathrm{Si}$ 系粒子が割れた隙間および周りにお いて，ミクロボイドが顕著に形成された。せん断帯上でより 顕著にミクロボイドが形成された。

（2）曲げ割れ初期の亀裂発生およびその伝播

曲げ加工度の増加に伴って最表層のミクロボイドが開口 し，割れの起点になる。この開口部に歪が局在化し，ミクロ ボイドとせん断帯に沿って割れが伝播する。ただし，ミクロ ボイドの開口部（割れの起点）の近傍にCube 方位粒が存在 する場合, せん断帯が形成されにくいため, 割れが伝播しに くくなる。

\section{謝 辞}

本研究の一部は, 公益財団法人科学技術交流財団主催の 研究会「X線トモグラフィーを利用した構造材料の信頼性向 上」の調査・研究活動に関わるものであり, 関係各位に御礼 申し上げます。また, シンクロトロン放射光実験を行った SPring-8（課題番号：2011B1111）に心より感謝します。

\section{参 考 文 献}

1) 浅野峰生, 箕田 正, 吉田英雄 : 軽金属学会第 106 回春期大会 講演概要, (2004), 5-6.

2) 浅野峰生，内田秀俊，吉田英雄：軽金属，52（2002），448-452

3) 浅野峰生, 箕田 正, 小関好和, 吉田英雄：軽金属, 56 (2006), 371-375.

4) 日比野旭, 村松俊樹, 佐賀 誠, 高田 健 : 軽金属, 53 (2003), 534-541.

5) 浅野峰生, 伊川慎吾, 松田公一, 吉田英雄 : 軽金属学会第 111 回秋期大会講演概要, (2006), 3-4.

6) 竹田博貴, 日比野旭, 高田 健 : 軽金属, 60 (2010), 231-236.

7) 戸田裕之, 小林正和, 鈴木芳生, 竹内晃久, 上杉健太朗 : 顕微 鏡, 44 (2009), 199-205.

8) H. Toda, K. Minami, K. Koyama, K. Ichitani, M. Kobayashi, K. Uesugi and Y. Suzuki: Acta Mater., 57 (2009), 4391-4403.

9) L. Qian, H. Toda, K. Uesugi, M. Kobayashi and T. Kobayashi: Phys. Rev. Lett., 100 (2008), 115505. 